\title{
INVESTIGATING THE MOTIVATION LEVEL OF STUDENTS IN ONLINE LEARNING IN JUNIOR HIGH EDUCATION INSTITUTION DURING PANDEMIC COVID-19
}

\author{
FARDANI ARFIAN \\ Pascasarjana PMIPA, Universitas Indraprasta PGRI, Jakarta \\ e-mail: arfianfardani@gmail.com
}

\begin{abstract}
The purpose of this study was to investigate and explore the level of junior high student's motivation during online learning in pandemic COVID-19. In this design-based research study, motivation level is examined by ARCS survey, interview and observation. The total of respondents were 180 students with different degree levels of study, gender and academic achievement. The analyzed data was measured by SPSS. From this research, the result shows that students of middle degree level have the highest motivation level during pandemic. A statistically significant difference in motivation level is also seen at the beginning of online learning and at the middle of online learning.
\end{abstract}

Keywords: ARCS Model, Motivation Level, Online-learning

\section{INTRODUCTION}

In 2020, WHO (World Health Organization) stated that the coronavirus disease (COVID-19) outbreak is a pandemic (World Health Organization, 2020). One of the recommendations from WHO to reduce the spread of COVID-19 and the effect of overwhelming health systems around is to implement social distancing procedures, which involves minimizing social and physical contact between people (Oosterhoff, B., et al., 2020 : 179-185). Social distancing includes not only in businesses and teleworking, but also in educational institutions (Alrefaie, Z., et al., 2020). Ministries around the world (including Indonesia) in every school and university recommend conducting learning through the internet, called online learning (Laurens, L. A. and Valdes, H., 2021).

In the beginning, the transformation of education from face to face learning to online learning, has encouraged major parties to make the learning system continue to run well, but actually, this system did not work as effectively as we imagined, in fact, not only students, parents, teachers, and the government also felt it (Alioon, Y., and Delialioglu, O., 2019 : 655668). One of the main issues regarding online learning during COVID-19 is the student's motivation (Lemay, D. J. \& Doleck, T., 2020). Student's motivation is the student makes an effort and pays attention to various activities. Students are likely to get motivated to learn via an activity even if they do not find the content interesting (Serkan, I., 2015).

Based on the explanation above, documenting the students' motivations, challenges, and the alternatives they put forward, is important to provide students on how to deal with such a critical learning situation. In this research, we adopted the design-based research (DBR) approach to analyze the motivational components to apply Keller's Attention, Relevance, Confidence, and Satisfaction (ARCS) framework.

One important thing of online learning are courses presented completely online, never meet the teacher or fellow student face-to-face, and may take online tutorials rather, interact with the teacher by social media or LMS (learning management system) and learn from texts as well as online resources (Li, K., and Moore, D., 2015). Being an independent student is the main thing to make distance learning successful (Chen, K. C. \& Jang, S. J, 2010). They should read outside the main materials to see issues and they actively attempt to change their learning skill.Thus, teachers must always improvise so that the learning conditions remain in accordance with the learning objectives (Muslimin A., I., 2020).

Nevertheless, online learning provides flexible opportunities in learning. On the other hand, instructors (teachers) can save time and cost by providing students with more suitable 
learning materials. The students show a positive attitude on online learning as it is convenient and efficient that they can use online learning anytime and anywhere. Besides that, online learning can help students to improve their computer/gadget skills that might be needed in the future job ( $\mathrm{Si} \mathrm{Na} \mathrm{Kew,} \mathrm{et} \mathrm{al.,} \mathrm{2018).} \mathrm{The} \mathrm{study} \mathrm{is} \mathrm{based} \mathrm{on} \mathrm{two} \mathrm{fundamental} \mathrm{assumptions:} \mathrm{1)}$ External conditions can influence confidence, and 2) Motivation is an essential element of learning (Li, K., and Keller, J., 2018). It shows that a student's motivation is one of the factors of success in learning. Motivation is defined as "that which accounts for the arousal, direction, and sustenance of behavior" (Keller, J., 1987) (Rasmitadila, 2020). In other words, motivation regulates the direction and amount of effort a learner expends on a task.

In the 1970's, Keller created an ARCS model. This model has been validated by other researchers. The ARCS model uses a systematic design process, beginning from analyzing the target audiences' motivations, designing motivational strategies based on the motivational analysis and other constraints, implementing the strategies and evaluating the effects (Moller, L. and Russell, J. D., 1994).

The ARCS model of motivation consists of four basic dimensions: attention, relevance, confidence, and satisfaction (J. Keller, 1987 : 45-52), which are described below (Keller, J., 1987) (Malik, S., 2014) : Attention (A) relates to generating the student's curiosity and sustaining the student's focus. This is accomplished through perceptual arousal, inquiry arousal, and variability in instruction. Relevance $(\mathrm{R})$ describes the importance of the instruction to the learner. It's accomplished through connecting the instruction to the student's experience, goal orientation, and motive. Confidence (C) refers to the student's positive expectations of success with reasonable effort and effect. It is accomplished through identifying the learning requirements, providing opportunities for success, and offering the learner personal control within the instructional materials. Satisfaction $(S)$ relates to the consistency of expectations with outcomes. It is accomplished through opportunities to use the new knowledge and skills, opportunities for positive consequences, and equity, which allows a learner to feel positive about his or her accomplishments through the application of consistent standards and consequences.

\section{RESEARCH METHOD}

In this research, we adopted the design-based research (DBR) approach to analyze the motivational components to apply Keller's Attention, Relevance, Confidence, and Satisfaction (ARCS) framework (Jale, S. B., 2008). There are three types of data collecting instruments, such as questionnaire of ARCS survey, interview and observation. The results were analysed quantitatively and qualitatively in order to gain better understanding on students' motivation levels in online learning and interpret what can be done to increase their level of motivation in online learning.

The total of respondents were 180 students with different degree levels of study, gender and academic achievement. 40\% (72 students) are male and 60\% (108 students) are female. That respondents have different degree levels of study, there are 60 students (33\%) in the 7th grade, 70 students (39\%) in the 8th grade and 50 students (28\%) in the 9th grade. Related to the research instrument, the first instrument that was used in this research was a questionnaire adapted from the ARCS model. This instrument is conducted in Bahasa languages. There were three sections in this questionnaire. In section A consisted of general demographic question items. In section B, there were 36 items to find out the students' motivation level. While, in section $\mathrm{C}$, it had one open-ended question to enable students to express their suggestions on how to enhance their motivation level in online learning and to write any further details about their opinions.

The second instrument was an interview. In this instrument, some questions were prepared to interview the potential interviewees to get reliable data and to discover what lies behind the answers of a question. Last instrument was an observation by a peer-researcher. By an observation's form, a peer-researcher step by step of research's implementation. All of the 
respondents who had followed online learning filled the questionnaires via $G$ form. The data collected from $\mathrm{G}$ form exported into Spreadsheet. Next, the data was imported into the SPSS software to be investigated in more detail about the students' motivation level according to the research question. After the questionnaires were collected, some selected students were invited to be interviewed to get clear data from them, and the conversations were recorded and analyzed qualitatively. Eight students were interviewed voluntarily. On the other hand, data from students' open-ended questions were analyzed using content analysis to help identify and summarize important issues that emerged.

\section{RESULTS AND DISCUSSION}

\section{RESULTS}

Four basic dimensions are attention, relevance, confidence, and satisfaction. These categories show more detail in Table 1. From each item on this table, we can find which categories should be improved to increase students' motivation level in online learning.

Table 1. Mean Score for Each Item of ARCS

\begin{tabular}{|c|c|c|c|c|}
\hline \multirow{2}{*}{ No. } & \multirow{2}{*}{ Item } & \multicolumn{2}{|c|}{ Mean } & \multirow[t]{2}{*}{ SD } \\
\hline & & \multirow{2}{*}{$\begin{array}{c}\text { Begin } \\
3.36 \\
\end{array}$} & \multirow[t]{2}{*}{ Mid } & \\
\hline \multicolumn{2}{|c|}{ Attention $(\mathrm{A})$} & & & .912 \\
\hline 1. & $\begin{array}{l}\text { I got something interesting when my } \\
\text { teacher start this online learning }\end{array}$ & 3.21 & 4.08 & 1.108 \\
\hline 2. & Some topic make me amazed & 2.89 & 3.23 & .794 \\
\hline 3. & $\begin{array}{l}\text { My curiosity had been stimulated in this } \\
\text { online learning }\end{array}$ & 3.14 & 3.14 & .843 \\
\hline 4. & $\begin{array}{l}\text { I fell so hard to keep my attention } \\
\text { because this lesson make me bored }\end{array}$ & 4.03 & 2.89 & 1.119 \\
\hline 5. & $\begin{array}{l}\text { Bad internet connection make me hard } \\
\text { to keep my attention }\end{array}$ & 4.08 & 4.08 & .808 \\
\hline 6. & $\begin{array}{l}\text { Any various media of online learning } \\
\text { help me to keep my attention during } \\
\text { online learning }\end{array}$ & 3.23 & 3.79 & .777 \\
\hline 7. & $\begin{array}{l}\text { Each page full of word so it's make me } \\
\text { disturbed }\end{array}$ & 3.79 & 2.93 & .934 \\
\hline \multicolumn{2}{|c|}{ Relevance (B) } & 3.38 & & .827 \\
\hline 8. & $\begin{array}{l}\text { The content of this topic is appropriate } \\
\text { to my interests }\end{array}$ & 3.93 & 4.16 & .554 \\
\hline 9. & $\begin{array}{l}\text { I could connected this topic in my daily } \\
\text { life and some thing that I have seen }\end{array}$ & 3.14 & 3.33 & .754 \\
\hline 10. & $\begin{array}{l}\text { These stories, diagram and example } \\
\text { show me important part of this topic }\end{array}$ & 2.87 & 3.86 & 1.165 \\
\hline 11. & $\begin{array}{l}\text { The topic of this online learning will be } \\
\text { beneficial to me }\end{array}$ & 3.86 & 3.86 & .808 \\
\hline 12. & $\begin{array}{l}\text { It's so important for me to finish this } \\
\text { lesson successfully }\end{array}$ & 2.89 & 3.87 & .809 \\
\hline 13. & $\begin{array}{l}\text { I already understand major of this } \\
\text { lesson, so it's not appropriate to my } \\
\text { needs }\end{array}$ & 3.60 & 3.60 & .763 \\
\hline 14. & $\begin{array}{l}\text { The style and content of this topic is } \\
\text { worth to know }\end{array}$ & 3.23 & 4.01 & .934 \\
\hline \multicolumn{2}{|c|}{ Confident (C) } & 3.57 & & .867 \\
\hline 15. & $\begin{array}{l}\text { I felt this topic would be easy for me } \\
\text { when my teacher start to teach }\end{array}$ & 3.20 & 3.97 & .995 \\
\hline
\end{tabular}




\begin{tabular}{|c|c|c|c|c|}
\hline 16. & $\begin{array}{l}\text { I knew what should I learn after I read } \\
\text { the preliminary information }\end{array}$ & 3.28 & 3.28 & .934 \\
\hline 17. & I believe I could learn this topic & 3.57 & 3.98 & .504 \\
\hline 18. & $\begin{array}{l}\text { There are so much information in that } \\
\text { slide, it's make me hard to pick out the } \\
\text { main point }\end{array}$ & 3.90 & 2.45 & .777 \\
\hline 19. & $\begin{array}{l}\text { Good content management helped me } \\
\text { believe that I would be able to learn this } \\
\text { topic }\end{array}$ & 3.97 & 4.16 & 1.023 \\
\hline 20. & $\begin{array}{l}\text { I don't really understand some of the } \\
\text { material in this online learning }\end{array}$ & 3.97 & 4.01 & .839 \\
\hline 21. & $\begin{array}{l}\text { I felt I could solve my anxiety during } \\
\text { online learning }\end{array}$ & 3.13 & 3.13 & .995 \\
\hline \multicolumn{2}{|c|}{ Satisfaction (S) } & 3.31 & & .756 \\
\hline 22. & $\begin{array}{l}\text { I enjoyed this lesson so much that I } \\
\text { want to know more about this topic }\end{array}$ & 3.61 & 3.91 & .802 \\
\hline 23. & $\begin{array}{l}\text { Any feedback and other comments after } \\
\text { practice on this online learning, help me } \\
\text { felt appreciated for my efforts }\end{array}$ & 2.89 & 3.44 & .978 \\
\hline 24. & $\begin{array}{l}\text { It's fun to work on well-designed online } \\
\text { learning }\end{array}$ & 2.87 & 3.93 & .833 \\
\hline 25. & $\begin{array}{l}\text { Finishing the exercises gave me a sense } \\
\text { of accomplishment }\end{array}$ & 3.23 & 3.23 & .729 \\
\hline 26. & $\begin{array}{l}\text { My teacher gave me opportunities to } \\
\text { explore my problem solving during } \\
\text { online learning, so I felt really enjoy } \\
\text { this lesson }\end{array}$ & 3.44 & 4.08 & .493 \\
\hline 27. & $\begin{array}{l}\text { I felt constrained by the rules of online } \\
\text { learning }\end{array}$ & 3.07 & 2.87 & .850 \\
\hline 28. & $\begin{array}{l}\text { It feels good to successfully complete } \\
\text { this lesson }\end{array}$ & 4.08 & 4.16 & .604 \\
\hline
\end{tabular}

From the data on the table, item number 2, item 9, item 21 and item 24 have the smallest mean for each category in the beginning of online learning. It means that relevance is the important point that teachers should be extra focused in order to increase the motivation level of students. While in the middle of online learning, most of the items for each category have increased, the biggest was item number 24 with different mean 1.08, and the item that had no change was item 21 . It shows students start to enjoy the online learning process and the teacher could make a well-designed online learning. On the other hand, item 21 shows that the internet was still one of the main problems of online learning. Next, the biggest mean for each category in the beginning of online learning were item 5, item 8, item 19 and item 28. It shows the teacher to maintain satisfaction when online learning activities.

Table 2 shows the student's motivation level between male and female students in online learning. From the table below, there was no significant difference between male and female students in motivation level during pandemic. Mean of male students was 3.87 and the mean of female students was 3.89. It can be concluded that there is no relationship between motivation level gender in online learning.

Table 2. Mean Score for Male and Female

\begin{tabular}{cccc}
\hline No. & Gender & Mean & SD \\
\hline 1. & Male & 3.87 & .482 \\
\hline
\end{tabular}




\begin{tabular}{llll}
\hline 2. & Female & 3.89 & .482 \\
\hline
\end{tabular}

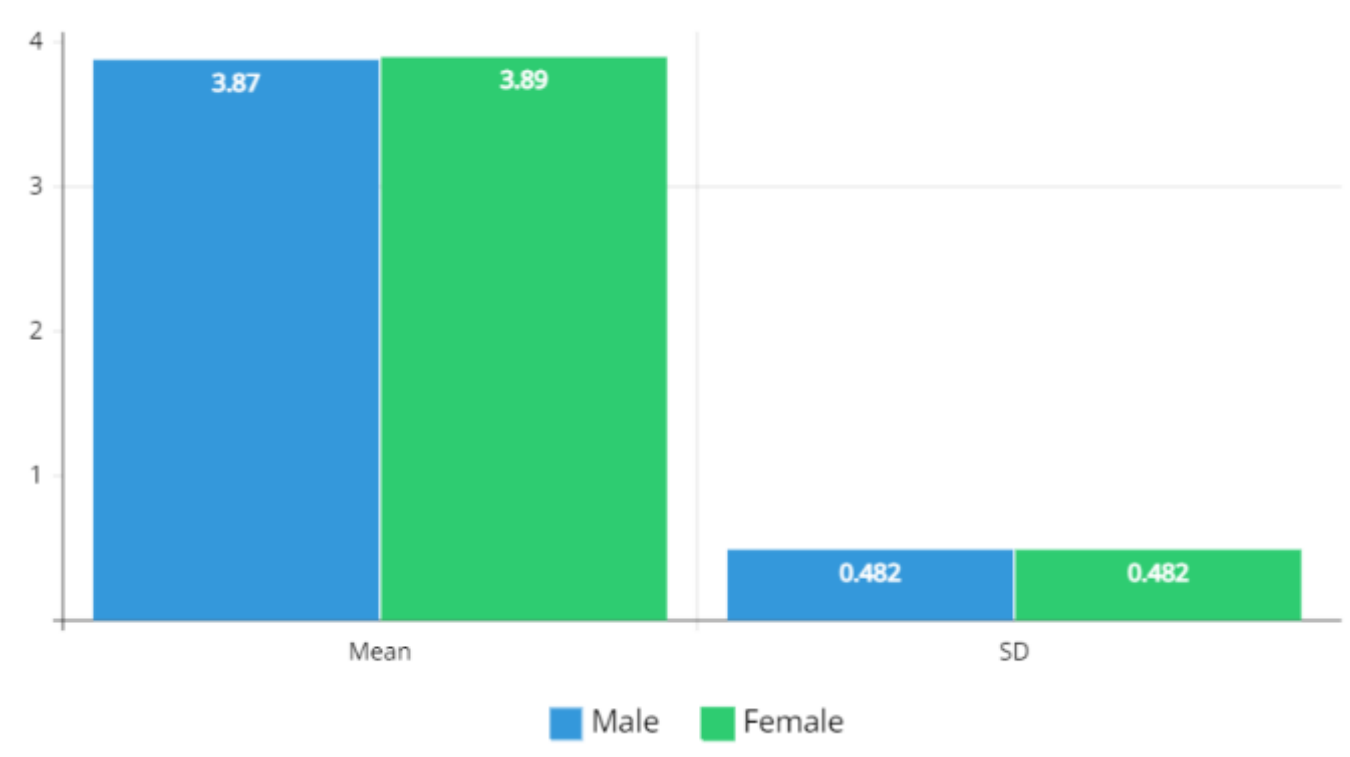

Picture 1. Mean Score for Male and Female

There were three level degrees such as 7 th grade, 8 th grade, and 9th grade. Motivation level for each degree can be shown in Table 3.

Table 3. Mean Score for Three Level Degrees

\begin{tabular}{clcl}
\hline No. & Level Degree & Mean & SD \\
\hline 1. & 7th grade & 3.72 & .554 \\
2. & 8th grade & 4.01 & .793 \\
3. & 9th grade & 3.37 & .680 \\
\hline
\end{tabular}

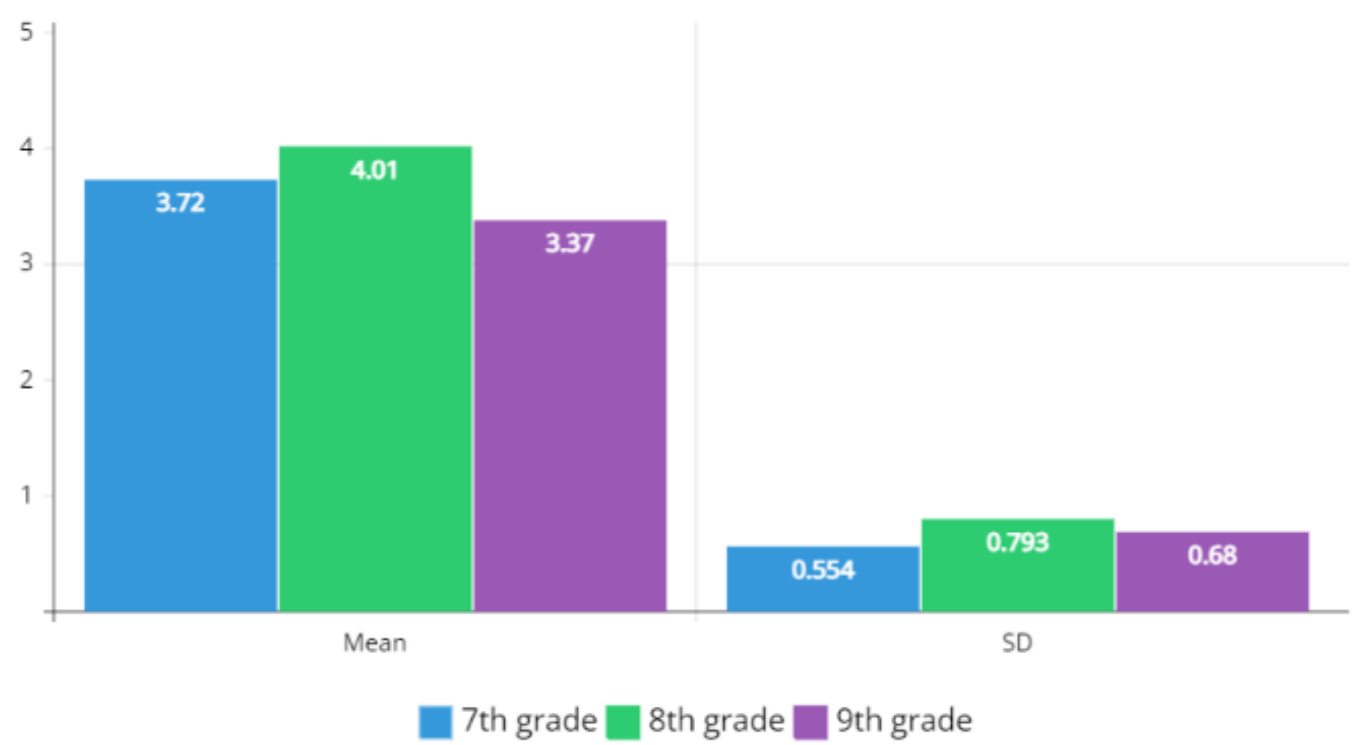

Picture 2. Mean Score for Three Level Degrees

From table 3 prove that a student in the 8 th grade has the biggest motivation level. The smallest is 9th grade. It shows that there was a significant difference between 7 th grade, 8 th grade and 9th grade. It is important for teachers to know strategies to make student's motivation enhance. By interviewing students we got students' suggestions to increase the motivation level of students in online learning. This information was summarized into various categories for other students, teachers, topic material and technical support. 
From students' categories, they said that in the beginning of online learning it's so hard to have inner desire to learn independently. But, in the middle of online learning they felt they enjoyed online learning because they can repeat their lesson anywhere and anytime they want. On teachers' categories, many information make any student felt hard to choose important point, it disturb their attention to teacher. Students suggest teachers to improve teaching models (such as not only slides but also fun online activity with ice breaking). Design a good lesson makes students enjoy and feel satisfaction. It will enhance the students' motivation.

Looking for technical support any student has anxiety during online learning. Sometimes the internet was not connected, so they couldn't access the lesson. Another problem was any student who doesn't have a handphone or laptop because they are not old enough. These four categories are the resume answers from respondents. Eventually there were so many ways to increase the students' motivation during online learning.

\section{DISCUSSION}

Based on the results shows that students of middle degree level have the highest motivation level during pandemic. Another result concludes that there is no relationship between motivation level gender in online learning. This result is the same with Yukselturk, et al. (2009) that there were not statistically significant mean differences among motivational beliefs, self-regulated learning variables and achievement in programming with respect to gender. Maybe actually this relates to a larger cultural or social problem that cannot be easily remedied. However, this research needs to be investigated further.

Followed by the results of interviews with respondents. At the beginning of online learning, they had demotivated to join the class because they were not satisfied with the welldesigned online. On the other hand, they have problems with infrastructure. Some of the students didn't have gadgets and internet connection. This result is in line with the research conducted by Saekow and Samson (2011), who found that students had made a complaint on the poor infrastructure of ICT. Another interview respondent emphasised that some subjects could not be taught by using e-learning, but face-to-face teaching. Hence, some teachers did not use online learning in teaching and students were also unable to understand the lesson in elearning without explanation and thus, they felt less motivated to access online learning.

More concern on students' motivation level, each ARCS categorised were analysed. The results show that the smallest mean were Satisfaction and Attention. Some students couldn't solve their anxiety during online learning. It's related to the results of the interview above. This point will encourage teachers to make better designing online learning activities. In the Attention category, item 2 "Some topic makes me amazed" has the lowest mean. This state might be a suggestion for teachers that it's so important to design online learning materials that can make students have curiosity with their topic, so they would be amazed and easily remember the important topic so as to enhance students' motivation. Nevertheless, the majority of students agreed that by online learning they can study their topic anywhere and anytime. This point was one of the advantages of online learning. Their teacher usually uploads materials such as documents and slides to e-learning for students, and they can download this material easily. They can also repeatedly complete assignments and try exams to improve their learning performance.

\section{CONCLUSIONS}

From this research, the result shows that students of middle degree level have the highest motivation level during pandemic. A statistically significant difference in motivation level also seen at the beginning and of online learning and at the middle of online learning.

\section{REFERENCES}

Alioon, Y., and Delialioglu, O. (2019). The effect of authentic m-learning activities on student on engagement and motivation. Br. J. Educ. Technol. 50 no. 2, pp 655-668. 
Alrefaie, Z., Hassanien, M., \& Al-Hayani, A. (2020). Monitoring Online Learning During COVID19 Pandemic; Suggested Online Learning Portfolio (COVID-19 OLP)", MedEdPublish, 9(1), from https://doi.org/10.15694/mep.2020.000110.1.

Chen, K. C., \& Jang, S. J. (2010). Motivation in online learning: Testing a model of self determination theory. Computers in Human Behavior, 26(4), 741-752.

Jale, S. B. (2018). Designing Motivational Learning Systems in Distance Education. Turkish Online Journal of Distance Education-TOJDE. Volume: 9 Number: 3 Article 13.

Keller, J. (1987). Development and use of the ARCS model of instructional design, J. Instr. Dev. 10, no. 2, 45-52.

Keller, J. (1987). Strategies for stimulating the motivation to learn. Perform. Instr. 26, 1-7.

Keller, J. (1987). The systematic process of motivational design. Performance and Instruction. Vol. 26(9-10), 1-8, b.

Laurens, L. A. and Valdes, H. (2021). M-learning adapted to the ARCS model of motivation and applied to a kinematics course. Comput Appl Eng Educ. pp 1-16, from doi : https://doi.org/10.1002/cae.22443

Lemay, D. J., \& Doleck, T. (2020). Online Learning Communities in the COVID-19 Pandemic: Social Learning Network Analysis of Twitter during the Shutdown. International Journal of Learning Analytics and Artificial Intelligence for Education (IJAI). 2(1), 85.

Li, K., and Keller, J. (2018). Use of the ARCS model in education: A literature review. Comput. Edu. 122, pp 54-62.

Li, K., and Moore, D. (2018). Motivating students in massive open online courses (MOOCs) using the attention, relevance, confidence, satisfaction (ARCS) model. J. Formative Des. Learn. 2, no. 1, pp 102-113.

Malik, S. (2014). Effectiveness Of Arcs Model Of Motivational Design To Overcome Non Completion Rate Of Students In Distance Education. Turkish Online Journal of Distance Education-TOJDE. ISSN 1302-6488 Volume: 15 Number: 2 A.

Moller, L. and Russell, J. D. (1994). An Application of the ARCS Model Design Process and Confidence-Building Strategies. Performance Improvement Quarterly. 7(4) pp. 54-69.

Muslimin, A. I. (2020). Online Learning during Pandemic: Students' Motivation, Challenges, and Alternatives. Loquen: English Studies Journal, from http://dx.doi.org/10.32678/loquen.v13i02.

Oosterhoff, B., et al. (2020). Adolescents' Motivations to Engage in Social Distancing During the COVID-19 Pandemic: Associations With Mental and Social Health", Journal of Adolescent Health. 67 79-185.

Rasmitadila. (2020). The Perceptions of Primary School Teachers of Online Learning during the COVID-19 Pandemic Period: A Case Study in Indonesia. Journal of Ethnic and Cultural Studies. Vol. 7, No. 2, 90-109.

Saekow, A., \& Samson, D. (2011). E-learning readiness of Thailand's universities compared to the USA's cases. International Journal of e-Education, e-business, e-Management and e-Learning, 1(2), 126-131.

Serkan I. (2015). Factors Motivating Preservice Teachers For Online Learning Within The Context Of Arcs Motivation Model. Turkish Online Journal of Distance EducationTOJDE. ISSN 1302-6488 Volume: 16 Number: 2 Article 5.

Si Na Kew, et al. (2018).Examining the motivation level of students in e-learning in higher education institution in Thailand: A case study. Educ Inf Technol, from doi : https://doi.org/10.1007/s10639-018-9753-z.

World Health Organization. Coronavirus disease 2019 (COVID-19) situation report e 62" . Available at: https://www.who.int/docs/default-source/ coronavirus/situationreports/20200322-sitrep-62-covid-19.pdf?sfvrsn 1/4755c76cd_2. Accessed April 1, 2020. 
Yukselturk, E. \& Bulut, S. (2009). Gender Differences in Self-Regulated Online Learning Environment. Educational Technology \& Society Vol. 12, No. 3, Technology Support for Self-Organized Learners, pp. 12-22. 